\title{
A NEW ISOTOMA OF THE SNOW FAUNA.
}

\author{
BY J. W. FOLSOM, URBANA, ILLINOIS.
}

This Canadian species of Isotoma is here described in order that its name may be used in a forthcoming article on insects of the snow by Mr. Charles Macnamara, after whom the new collembolan is named. He writes: "This species seems to be confined to wooded swamps; I have never seen it elsewhere; and it sometimes comes out on the snow in small numbers. This is the only pugnacious springtail I have ever observed. It almost always attacks an Achorutes put in the same vial with it and sometimes kills it."

\section{Isotoma macnamarai, new species.}

Olive green. Legs and furcula pale. Body segments bordered narrowly with black. Head conspicuously large in proportion to the body (fig. 1). Eyes (fig. 2) $8+8$, on black patches. Postantennal organs absent. Antennæ four-fifths as long as the head, with segments in relative lengths as $8,12,13,21$; fourth segment elliptical. Sense organ of third antennal segment with two geniculate sense clubs (fig. 3). Fourth antennal segment with slender curving sense hairs. Unguis stout (fig. 4), with a proximal outer pair of small teeth and with a conspicuous inner tooth one-third from the base. Unguiculus more than half as long as unguis, broadly lanceolate, unidentate at the middle of the inner margin. Tenent hair single, unknobbed. Third and fourth abdominal segments subequal in length. Fifth and sixth abdominal segments not ankylosed. Furcula apparently appended to the fifth abdominal segment, gradually tapering and short, extending a little beyond the posterior margin of the second abdominal segment. Manubrium and dentes subequal in length. Dentes crenulate dorsally. Mucrones two-fifths' as long as hind ungues, quadridentate (fig. 5); apical tooth short, not hooked; second and third teeth large, subequal; fourth small, lateral, at base of third. Rami of tenaculum quadridentate; corpus with ventral setæ. Clothing of abundant strong curving setæ of moderate length (fig. 6), with long, outstanding, simple sensory setæ, of which there are several pairs on the fourth and the fifth abdominal segSeptember, 1918 
ments, and one pair on each of the remaining segments except the prothoracic, which has none. Maximum length, $1.8 \mathrm{~mm}$.

This species is nearest Isotoma grandiceps Reuter, from Siberia and St. Lawrence Island, Alaska, but differs from the description of grandiceps, particularly in the form and markings of the head, the colour of the body, number of eyes, and number of mucronal teeth.

Arnprior, Ontario, Canada, December to April, inclusive; Charles Macnamara. Ten cotypes.

\section{Explanation of Plate ViI.}

Isotoma macnamarai.-Fig. 1. Dorsal aspect, from photomicrograph by Mr. Macnamara, X 35. Fig. 2. Eyes of left side, $\mathrm{X}$ 346. Fig. 3. Sense organ of third antennal segment of right side, $\mathrm{X}$ 1120. Fig. 4. Right hind foot, X 653. Fig. 5. Right, aspect of right mucro, $\mathrm{X} 653$. Fig. 6. Setæ, median dorsal line of third abdominal segment, $\mathrm{X} 346$.

\section{ENTOMOLOGICAL COLLECTIONS OF THE LATE W. H. HARRINGTON.}

The Entomological Collections of the late Mr. W. H. Harrington have been acquired by the Entomological Branch of the Department of Agriculture, Ottawa, and will be incorporated in the Canadian National Collection of Insects. The collection is particularly rich in the parasitic families of the Hymenoptera in which Mr. Harrington was specially interested. It contains a number of types of Provancher's species, as indicated in Messrs. Gahan and Rohwer's account of the "Lectotypes of the Species of Hymenoptera (except Apoidea) described by Abbé Provancher," given in several issues of The Canadian Entomologist from volume 49, No. 9 , p. 298 to volume 50 , No. 6 , p. 196 ; accordingly, any types described as being in the Harrington Collection will now be found in the National Collection at Ottawa.

September, 1918 


\section{$2 \mathrm{BHL}$ Biodiversity Heritage Library}

1918. "A new Isotoma of the snow fauna." The Canadian entomologist 50 , 291-292. https://doi.org/10.4039/Ent50291-9.

View This Item Online: https://www.biodiversitylibrary.org/item/22125

DOI: https://doi.org/10.4039/Ent50291-9

Permalink: https://www.biodiversitylibrary.org/partpdf/22092

\section{Holding Institution}

MBLWHOI Library

Sponsored by

MBLWHOI Library

\section{Copyright \& Reuse}

Copyright Status: NOT_IN_COPYRIGHT

This document was created from content at the Biodiversity Heritage Library, the world's largest open access digital library for biodiversity literature and archives. Visit BHL at https://www.biodiversitylibrary.org. 